\title{
The Impact and Compensation of Offshore Wind Farm Development: Analysing the Institutional Discourse from a French Case Study
}

\author{
Kermagoret Charlene ${ }^{1,{ }^{*}}$, Levrel Harold ${ }^{2}$, Carlier Antoine ${ }^{3}$ \\ ${ }^{1}$ Univ Western Brittany, UMR AMURE, IUEM, F-29238 Brest 3, France. \\ 2 IFREMER, Ctr Brest, UMR AMURE, Marine Econ Unit, F-29280 Plouzane, France. \\ ${ }^{3}$ IFREMER, DYNECO, Benth Ecol Lab, F-29280 Plouzane, France.
}

Corresponding author : email address : charlene.kemragoret@ifremer.fr

\begin{abstract}
:
In France, the public acceptability of marine renewable energies and their impacts on ecosystem services (ES) involves questions about compensation for stakeholders, who may perceive some of their activities and interests to be modified. This paper seeks to understand how impacts on ES are perceived by institutional stakeholders and what is expected in terms of compensation. It also seeks to identify the communities of practice affected. We focus our study on the planned offshore wind farm in the bay of Saint-Brieuc. Our results show that institutional discourse is heterogeneous, depending on sensitivities, interests, and who or what the stakeholders surveyed represent or defend. Stakeholders' discourse can be interpreted on various gradients of perception. Six distinct communities of practice have been identified, based on the impacts perceived by institutional stakeholders. Lastly, we show that the community of practice seems to be a proper level at which to study perceptions and assess the nonet-loss goal.
\end{abstract}

Keywords : communities of practice, ecosystem services, compensatory measures, no-net-loss goal, arine renewable energy, offshore wind farm 


\section{Introduction}

As part of Europe, France is politically committed to several objectives relative to the reduction of greenhouse gases. Among them, it must ensure a rapid development of renewable energy exploitation (European Commission, 2008). The French government has chosen to exploit its maritime potential in developing marine renewable energy including offshore wind energy. In northern European countries, where these technologies are widely developed, the deployment of offshore wind farms has partly alleviated major environmental and societal problems resulting from onshore projects (Still, 2001; Ladenburg and Möller, 2011). However, the first offshore installations were not readily accepted by local populations (Firestone and Kempton, 2007). Even though these technologies form part of a sustainable development approach, they can also have an impact on ecosystems, other human activities, and landscapes (Boehlert and Gill, 2010). Gill (2005) highlights significant physical disturbance of the coastal ecology during the construction and operational phases of offshore wind farms. These modifications of the environment can produce conflicts among interest groups such as energy companies, the fishing sector, and pro-environment activists (Inger et al., 2009; Haggett, 2011; Château et al., 2012). These technologies can also be viewed by local stakeholders as threatening the natural beauty of a site and some local residents would be ready to pay higher costs per kWh produced in order to keep a wind farm away from the coast (Ladenburg and Dubgaard, 2007; Devine-Wright and Howes, 2010). Thus, Kuehn (2005) shows from two case studies that opposition to offshore wind farms is mainly based on aesthetic concerns and suggests that time, adaptation and communication about the projects may contribute to a change of opponent attitudes.

In France, the call for tenders launched in 2011 and 2013 for the exploitation of offshore wind farms clearly mention compensation as a tool to overcome residual environmental concerns and social conflicts. This socio-environmental compensation has a overall goal of territorial equity and social acceptability of projects (Gobert, 2010; Gastineau and Taugourdeau, 2014). From a theoretical point of view, compensation must satisfy the objective of "no net loss" and can be understood in terms of the ecosystem services (ES) provided by marine biodiversity. The concept of ES can be seen as a valuable frame of reference for assessing changes in the material and non-material determinants of human well-being resulting from offshore energy projects (Gee and Burkhard, 2010; Busch et al., 2011). To understand better how the concept can be used in a negotiation process, two main questions will be discussed in this paper:

(1) How are impacts on ES perceived by institutional stakeholders and what compensation is expected?

(2) How the perceptions expressed by institutional stakeholders may be used to identify the various communities of practice who each share a different understanding of the implications of renewable offshore energy?

Our case study is the planned offshore wind farm in the bay of Saint-Brieuc, one of the four sites selected by the first French national tender process.

\section{Conceptual background}

\subsection{Compensations}

Socio-environmental compensation has a goal of optimal distribution of benefits within the territory to ensure both social and ecological fairness. On the one hand, it is based on a clear legal framework that imposes the "avoid, reduce, offset" guidelines for environmental 
damages (Cuperus et al., 1999). On the other hand, it comes from pragmatism of the developers who implement compensation for victims in order to increase the social acceptability of projects (Gobert, 2010). Thus, the socio-environmental compensation can take many forms such as monetary incentives, public goods or biodiversity offsets according to the objective. In a context of an offshore wind farm, compensation may be considered as ecological restoration actions that target impacted species or ecological habitats (Cole, 2009). On the other hand, compensation may be considered in monetary terms for some affected stakeholders like fishers and should be paid to individual or into a trust fund set up to benefit fishers collectively (Gray et al., 2005).

Theoretically, compensations aim to achieve a no-net-loss balance of ES, which can be assessed using either an ecological frame of reference or one based on human well-being (McKenney and Kiesecker, 2010; Dunford et al., 2004) (Figure 1). Reality is mainly based on a negotiation process carried out upstream of the projects to estimate the values of losses and thus recognize and reallocate the negative externalities (Gobert, 2010).

\subsection{Ecosystem services}

ES are generally defined as the benefits obtained from ecosystems, deriving from ecological processes and functions (MEA, 2005). Including these services in the planning process should help in taking into account the various ecological functions provided by biodiversity, and not only the economic resources produced. In short, the use of this concept aims to reconcile policies relative to biodiversity conservation with those relative to economic development. Thus, the ES concept quickly surpassed the academic community and was introduced into some regulatory frameworks, in particular through the principle of compensation (UICN, 2011). ES can be divided into several categories (MEA, 2005):

- Provisioning ES resulting from direct harvesting of ecosystem resources;

- Regulating ES deriving from the regulating processes of ecological functions that humans benefit from;

- Cultural ES contributing to the cultural, aesthetic, and psychological dimensions of well-being.

These three categories of service rely on different sources of values. In environmental economics, a distinction is made between use values and non-use values. Use values concern the market and non-market services that the environment provides to humans both directly (such as fish stocks for recreational or commercial fishing) and indirectly (tide protection, pest control, filtering functions). They also include the benefits derived from potential future use (option values). Non-use values are based on the mere existence of an environmental component, whether or not it is used, and also on certain ecological or landscape features that will be preserved for future generations (CAS, 2009; Pearce and Turner, 1990). Thus, the values attributed to these ES depend upon the stakeholders who benefit from the services (Hein et al., 2006). In the context of offshore wind farm, Mangi (2013) shows that the induced changes on ES concern all three categories of ES and that their evaluation requires the involvement of multiple stakeholders.

\subsection{Stakeholder involvement: from institutional stakeholders to communities of practice}

Stakeholders are defined by Freeman (1984) as "any group or individual who can affect or is affected by the achievement of an organisation's purpose" and more specifically by Röling and Wagemakers (1998) as "natural resource users and managers". Thus, the use of the concept of stakeholder is a relevant framework for understanding managerial decisionmaking by taking into account the heterogeneity between individuals. However the concept can be approached in different ways depending on interests, ways of perceiving problems, or 
opportunities relative to the subject under investigation. Not all stakeholders have the same stake or level of interest in the marine environment where issues are multiple (Pomeroy and Douvere, 2008). This raises the question of how to identify the stakeholders in a specific situation and which stakeholders deserve or require attention (Mitchell et al., 1997). A scheme of stakeholders' scales is proposed in Figure 2 including institutional stakeholders, communities of practice, and individuals.

Institutional stakeholders are defined here as those who represent or defend a sectorspecific interest. They depend on an organisation to fulfil their own goals, and the organisation depends on them in turn (Johnson and Scholes, 1999). Organisations may be municipalities, associations, committees, counties, sports clubs, and so on. They are known to the population because they represent a specific sector. Institutional discourse, which is carried out by institutional stakeholders, has been identified as a category of talk and has been described as an example of strategic discourse (Habermas, 1984). It is power laden and goal-directed, based on the homogenisation and the standardisation of the individual stakeholders' discourses represented by the organisation.

Communities of practice (CoPs) offer more specific descriptions of perceptions than institutions. A CoP is defined as a group of people sharing language, experiences, and knowledge through involvement in a similar activity (Arias and Fischer, 2000). A CoP is created over time in the pursuit of a common goal and is characterised by strong social relationships (Wenger, 2000). It can be defined in various ways: by size, the geographical scale on which it is active, or its institutional position (Wenger, 1998). The interactions that practitioners sustain among themselves within each CoP also lead to common social representations about an object, an activity, an idea or an event such as an offshore wind farm (Levrel, 2006; Amin and Roberts, 2008). In this study, we assume that the concept of CoP is used to help us establish a clear link between stakeholders and ES categories. In fact, a CoP can be defined by a shared interest in the use of specific ES. For example, environmentalists are attentive to the assessment of regulating services while scuba divers focus on cultural services. Analysing these links can help us develop targeted information for communicating with various CoPs (Levrel et al., 2007).

The third group is that of the individual stakeholders. They can be defined as citizens who are interested in, involved in, or affected by some project, and can belong to one or more CoPs. Individual perceptions are more specific and detailed, but eliciting them requires more effort given the need to ensure that they address all the relevant issues in a truly representative way.

We assume that descriptions of perceptions will be more specific the closer we get to the individual level. However, field work carried out at the individual level is most difficult to achieve if the representativeness of existing perceptions is sought. In this study, we focus our attention on perceptions of institutional stakeholders as the important first step of an extensive study describing social representations of a planned offshore wind farm. The importance of focusing on institutional stakeholders firstly, is that they are easily identifiable in the territory and further, they have a relatively good knowledge of the project and an integrated vision, which leads to well-constructed perceptions. Through the institutional discourse, we also seek to identify the CoPs directly affected by the project as a first step towards a broader analysis of perceptions. 


\section{Materials and methods}

\subsection{Case study}

The study was conducted in the bay of Saint-Brieuc, where an offshore wind farm is planned. The bay, on the French coast in the western Channel (Figure 3), has a coastline of $115 \mathrm{~km}$, bordered to the west by the island of Bréhat and to the east by Cap Fréhel. There are 23 municipalities along the coast, Saint-Brieuc being the largest one with 50,000 inhabitants. The main economic activities are commercial fishing and tourism. Because of its history and economic dominance, commercial fishing in the bay of Saint-Brieuc is particularly important and diversified (Augris and Hamon, 1996). Great scallop (Pecten maximus) is the main targeted commercial species and has a strong patrimonial value for the territory's population.

The bay of Saint-Brieuc is attractive for tourists owing to the presence of remarkable sites such as Bréhat island, Cap d'Erquy, and Cap Frehel, which provide a panoramic view, and a large diversity coastal landscapes in which sandy or muddy beaches alternate with rocky outcrops (Bertin, 2011). The bay of Saint-Brieuc is also a biodiversity hotspot, as demonstrated by the various regulatory frameworks applied to it. The Natural Reserve of the bay of Saint-Brieuc was created in 1998 to preserve the natural heritage, especially the avifauna and their habitats. A total of 1864 ha of the bay is listed as a Natura 2000 site (including 1034 ha of marine areas). Recently, the bay has also been included in a planned marine park. These management tools must contend with major regional issues, including invasive species, green algae proliferation and multiplication of human coastal activities, including marine renewable energy developments.

The planned offshore wind farm involves the deployment of 100 wind turbines, designed to generate $500 \mathrm{MW}$, spread over an area of $80 \mathrm{~km}^{2}$ situated $16,2 \mathrm{~km}$ off the coast, with the investment of 2 billion Euros. It is to increase electricity production with the goal of generating $8 \%$ of total electricity consumption in Brittany.

\subsection{Open-ended interviews}

A range of local "institutional" stakeholders were identified in order to be sure of taking into account most of the major issues related to offshore wind farm deployment and thereby a maximum of society-nature interactions. Stakeholders interviewed included political figures, managers of natural areas, economic actors, heads of public organisations, recreational associations, commercial fishers, and industrial wind companies. In May and June 2012, 24 semi-structured interviews were conducted with institutional stakeholders (Table 1). Most of them have been easily identifiable because they are involved in the project and, as a consequence, they are often mentioned in press articles and during discussions with first stakeholders interviewed. Others who are less invested in the project have been incorporated into the sampling plan because we have identified them as potentially affected by the project. Discussions were organised around four points: (i) the degree of knowledge and involvement of the organisation in the planned offshore wind farm; (ii) the presence or absence of organised groups supporting specific interests or strategies relative to the wind farm; (iii) perceptions of impacts (positive and negative) of the wind farm; (iv) perceptions of the compensation that would be needed to balance the impacts. The length of the interviews varied from 90 to 120 minutes. Some key questions were used as a guideline in order to cover all the categories of potential impacted ES when the conversations did not range widely enough. These questions were open-ended, with the possibility of pursuing clues that came up during the interviews. Open-ended interviews have the advantage of allowing a great freedom of talk for respondents and to collect all the issues inherent to the object of study. However, this method does not allow a quantitative analysis of the results and does not identify the influence of social factors in discourses, thus the interpretation of the results 
must be carried out with caution. In this study, the transcribed interviews were analysed with the aims of describing issues related impacts and compensations about the planned offshore wind farm; identifying the main communities of practice affected by the project; and finding out how perceptions are shaped within each CoP. Answers related to potential impacts and compensations have been analysed and then characterised from the three categories of ES i.e. provisioning ES, regulating ES and cultural ES.

\section{Results}

\subsection{Main perceived impacts on ES}

Perceptions of impacts on ES are widely heterogeneous in the sample, depending on the sector-specific interest represented or defended by the institutional stakeholders. As requested, general perception takes into account the three categories of ES and covers a large number of society-nature interactions. The results are summarised in Table 2 and analyzed by class of ES to which they refer.

\subsubsection{Perceived impacts on provisioning ES}

The perceived impacts on ES concern two different provisioning services: provision of food through commercial fishing and provision of clean energy through wind exploitation. The former is widely perceived as being negatively impacted by the offshore wind farm during the deployment and exploitation phases. This opinion was shared by the majority of institutional stakeholders surveyed, except for managers of natural areas who highlighted the potential "reserve" effect, which may increase fish and shellfish stocks. However, it was also assumed that the offshore wind farm will be a source of clean energy for the local community and thus represents a positive impact with respect to provisioning ecosystem services.

Since commercial fishers were invited to participate from early on in the consultation phase of the project, they have a clear perception of the impact of the wind farm on their activity: (1) loss of exploitable area and problems of access, especially for trawling gear due to the size of the wind farm; (2) changes in water quality during the construction phase and its indirect effect on benthic habitats; (3) ecological impacts on exploitable resources during the operational phase; (4) navigational hazards and environmental implications linked to undersea cable installation. In order to minimise impacts on provisioning $E S$, the wind farm company negotiated early with professional fishers in order to adapt the project to suit them. While the final decision on the right to navigate through the wind farm will be made by the prefecture, many institutional actors expressed reservations about the real capacity of fishing boats to navigate and work around the turbines.

"There will be no more boats on this still relatively young scallop bed." (Commercial fisher) "The operators are very removed from the reality on the ground and local constraints, there may be some surprises." (Political figure)

The positive impact on the provision of clean wind energy for electricity generation was mentioned in some interviews. The farm is supposed to overcome the energy dependence of Brittany on other regions (in particular because there are no nuclear plants in Brittany). This argument is sometimes counterbalanced with other impacts on the territory and its ecosystems, such as the modification of the landscape.

"The project would account for $17 \%$ of the energy autonomy of Brittany, it requires some compromises." (Political figure) 


\subsubsection{Perceived impacts on regulating ES}

The perceived impacts on regulating ES vary depending on the geographical and the spatial level taken into consideration. Since the offshore wind farm is seen as a contributor to global climate regulation, the project is perceived quite favourably by environmentalists. They see it as a better alternative than the previously planned natural gas processing plant close to Saint-Brieuc which they opposed a few years ago. On the local geographic level, regulating ES seem to be threatened. However, the survey's results show that it is difficult to represent the nature and extent of the impacts because of the many scientific uncertainties involved. Most stakeholders agreed with the project leader's decision to use jacket foundations rather than gravity base foundations, with the assumption that the former will have a lower impact on ecosystems. Environmentalist stakeholders are waiting for the environmental impact assessment before commenting on the impact on regulating ES. Lastly, there are some misunderstandings regarding the installation of an industrial site near a natural site (marine Natura 2000).

The political and economic institutional stakeholders have a more optimistic perception of the impacts on regulating ES. Apart from temporary disturbances during the construction phase, no negative impacts are anticipated. The expected reef effect of turbines' foundations is viewed as a positive impact on the marine ecosystem, even though some concerns are voiced.

"How are these new ecosystems going to evolve? Will there be changes in the species that are present?" (Political figure)

\subsubsection{Perceived impacts on cultural ES}

Perceptions of predicted changes in the aesthetic character of the landscape of the bay of Saint-Brieuc seem to vary widely within the population surveyed.

"I do not know what to think about the visual impact; it is difficult to have a clear idea of it." (Commercial fisher)

"If it's a matter of what the landscape looks like, we can get used to it." (Commercial fisher)

"The eye is naturally drawn to the turbines, even if we want to ignore them." (Economic actor)

Photomontages made by the project leader have been presented to stakeholders during public meetings around the bay. The image of a "matchstick on the horizon" used to describe the appearance of a wind turbine came up several times, to argue that the visual impact would be almost insignificant. The tourism industry seems less concerned by the visual impact. The fact that the planned offshore wind farm may become an attraction was brought up. Managers of natural areas do not think that the project will attract more tourists, who come mainly for the diversity of natural landscapes in the bay of Saint-Brieuc. The stakeholders belonging to recreational associations do not expect any direct impact on their activities. While scuba divers seem to be interested in benefiting from the new hard sub-sea landscapes, which may attract more diverse fish assemblages, a decline in clubs attendance because of the feared visual impact.

\subsection{Compensation expected by institutional stakeholders for the perceived impact on ES}

Institutional discourse about expected compensations is restricted to stakeholders who perceived some negative impacts on ES (Table 2). Once again, it is very heterogeneous according to the stakeholder to which it refers. Institutional discourses also focus on different types of compensation. 


\subsubsection{Monetary incentives}

An annual tax based on the electricity produced by offshore wind farms will be a source of 14,000 Euros per year per megawatt ${ }^{1}$. The definition of this tax has been designed partially on negotiations between stakeholders and the French government. For example, because of the nature and the intensity of the impacts on their activity, professional fishers managed to increase the part of the tax which would return to them. An agreement has also been concluded to ensure that these funds benefit exclusively the projects carried out by the departmental fisheries committees directly affected by the planned offshore wind farms. Five municipalities are eligible for this tax and a sixth has attempted to integrate the scope of the tax arguing the existence of an island off its territory. The hotel industry also made a request to receive some of this tax money so that it could use it to bring hotel facilities in the region up to code as needed. In the end this request was rejected. Except for those who are directly affected, most of the stakeholders are unaware of this tax.

In addition to the tax, which provides a financial return for local authorities and stakeholders, some specific compensatory measures have been planned to compensate for specific impacts. These compensatory measures take into account the loss of activity associated with the wind farm's construction and use. With respect to loss of activity, it seems that only fishers have been considered eligible to benefit from compensatory measures. All fishers will have to submit documents to prove the impact of the wind farm on their own production. The departmental fisheries committee, who is responsible for dividing the overall allocation among individual fishers, is already concerned about future administrative confusion in the process. No other institutional stakeholders have made claims to monetary incentives.

\subsubsection{Accompanying measures}

Accompanying measures consist in funding actions or public goods to support the development of impacted activities. Unlike compensatory measures, they are not assessed from a specific impact and their limitations seem quite fuzzy. They are bilaterally negotiated with key stakeholders. Most of the accompanying measures benefit commercial fishers, giving them short-term funding while they wait for the long-term funding from the tax revenue to start in 2018. Formal agreement has been reached on eight accompanying measures, five of which have been made public so far: creating a new position devoted to the "energy issue" in the departmental fisheries committee; funding for projects to control the invasive species slipper limpet (Crepidula fornicate), an invasive benthic species; installation of chilled tanks for lobsters; great scallop reseeding; and funding a scientific study of the reef effect of the wind turbine foundations. These actions have been desired for many years by the departmental fisheries committee that takes advantage of this financial opportunity to carry out their projects. Moreover, a 10-year commitment to finance equipment for sailing clubs was negotiated between the project leader and some representatives of recreational users.

While these measures are already negotiated, other institutional stakeholders hope the implementation of additional accompanying measures to support the territory development. For example, a political actor has claimed to represent the most affected municipality because of impacts on landscape, ecological habitats, and fishing - in order to have the harbour chosen as the site of maintenance work on the wind farm and thus indirectly to gain

\footnotetext{
${ }^{1}$ This fund will be used by the National Fund for Compensation of offshore wind energy, as follows: - $50 \%$ of the amount will be given to the coastal towns where the turbines will be visible. To benefit from the fund, the maximum distance from the turbines is 12 nautical miles.

- $35 \%$ will be allocated to the National Fisheries Committee to fund projects promoting sustainable exploitation of fishery resources.

- $15 \%$ will finance projects contributing to the sustainable development of maritime activities.
} 
related jobs for the town. A recreational association would like to have some artificial reefs installed in the bay if that becomes possible.

\subsubsection{Biodiversity offset}

Ecological compensatory measures seem to be less definable, as potential ecological impacts of offshore wind farms remain difficult to assess. Then, compensatory measures will be based on the outcome of the Environmental Impact Assessment. The results of environmental studies will be publicly available very late in the offshore wind farm planning procedure, after a consultation process and a public debate. One danger is that environmental stakeholders will encounter constraints when they make claims against the planned offshore wind farm or seek to participate in designing compensatory measures. However, the fishing industry has negotiated some protocols for monitoring fish stocks; these negotiations have led to agreements in which wind farm operators agreed to follow the protocols and implement measures to offset impacts.

\subsection{Definition of CoPs in terms of perceived impacts}

Six CoPs which each share a different understanding of the implications of the planned offshore wind farm have been identified from the institutional discourse. Links between these CoPs and ecosystem services have been identified and compiled in Table 3.

(1) Scallop fishers are concerned about negative impacts of the offshore wind farm on the shellfish stock. Great scallop has high economic and social value in the bay of Saint-Brieuc. This is the oldest fishing activity here and the bay is closely associated with this species. Most of the fishers in the bay are involved in it. The fishery fleet employs about 400 people in the bay, based in the maritime districts of Paimpol, Saint-Brieuc, and Saint-Malo.

(2) Trawl fishers are affected by an additional impact related to the difficulty of manoeuvring among turbines. While a minimum distance between two turbines has been negotiated to allow fishing in the wind farm area, some of those surveyed believe that trawling will no longer be possible in the wind farm area. Trawl fishers thus perceive the planned offshore wind farm more negatively than other fishers. Trawling in the bay of Saint-Brieuc is a secondary fishing activity as a complement to scalloping, and concerns mainly fishers from the maritime district of Saint-Brieuc.

(3) Members of naturalist Non-Governmental Organisations (NGO) are in favour of renewable energy developments, but expressed reservations about the offshore wind farm's impact on ecosystem functioning at the local level. They do not feel strongly about the project but remain attentive to the progress of the environmental impact assessment. The naturalist NGOs are grouped into five associations with thousands of members, of whom only a minority is really active. They have in-depth knowledge of ornithology, mammalogy, and more generally the ecology of land and coastal systems.

(4) Six recognised associations for environmental protection are grouped into a collective movement opposing the planned offshore wind farm. Members of these environmental associations are perceived by other institutional stakeholders as focused on individual interests related to the landscape impact of the offshore wind farm. On their side, they claim a lack of information and consultation on the part of the operators, as well as poorly understood environmental impacts. This movement includes nearly a thousand people, mostly second-home owners on the east coast of the bay. It is now seen by the operators as the most likely source of litigation.

(5) Tourists do not constitute a formal movement, but they share some specific perceptions, which lead us to treat them as a CoP. They seem to be sensitive to the aesthetic aspect of 
the landscape. They are not really aware of impacts and compensation and do not feel well informed about the planned offshore wind farm. Hundreds of thousands of tourists visit the bay each year and are a major source of income for the local economy; it is thus important to take them into account in the future.

(6) Recreational users feel a concern with the planned offshore wind farm but find it difficult to understand the associated impacts. Organisations hosting recreational activities are poorly informed about it, but do not exclude the possibility of taking advantage of it to develop new activities. Recreational activities along the coast are numerous in the bay of Saint-Brieuc. Recreational users fall into three main subcategories:

(i) Recreational fishers include thousands of people in the bay of Saint-Brieuc, fishing from the shore or from boats. They target various species and are sometimes in conflict with commercial fishers. They do not expect any impacts, but would like to benefit from compensation such as artificial reef installations in the bay.

(ii) Sailing is popular in the bay. Ten water sport clubs offers trips around the bay and towards the Channel Islands. There is concern that there may be a loss of the "sense of freedom" associated with this activity.

(iii) Scuba divers benefit from the biodiversity of submarine life in Brittany. Several diving club excursions are available in the bay. Opinions vary with respect to the potential reef effect of wind turbines: it is perceived positively by some and negatively by others.

\section{Discussion}

The discourses offered by institutional stakeholders are extremely heterogeneous and depend on their sensitivities, interests, and who or what those surveyed represent or defend. The level of knowledge of the respondents is also an important factor, since it influences the perception of impacts and the compensation claims (Arnold, 2004).

Initially, the selection of institutional stakeholders was aimed at covering all the potential impacts on ES of the planned offshore wind farm. The distribution of perceived impacts across the local population is now better understood (Table 2). Discourses can be differentiated in terms of the perceived cumulative impact (positive or negative)

- Only positive effects,

Economic actors (industrial wind companies and local economic actors) perceive no negative impact. These institutional stakeholders do not consider environmental impacts (Gray et al., 2005). The planned offshore wind farm is a stimulus to job creation and a source of profit for private companies both locally and nationally. The project is all the more acceptable in that it fits into a sustainable development strategy.

- Balance of positive and negative effects,

Political figures make the link between local economic interests and environmental concerns. Their discourses are more moderate, balancing negative impacts (on fishing, landscape) and positive ones (on global climate regulation, electricity production).

- Major negative impacts,

Other institutional stakeholders surveyed (local NGOs, commercial fishers, and recreational activity organisations) perceived major negative impacts on the various components of ecosystems. 
The perception of negative impacts is the necessary criterion for claiming compensation. Three types of discourses of the right to compensation have been identified:

- Opportunistic discourse: "Others receive compensation, what about me?"

No significant impact is perceived by these stakeholders, but the idea of benefiting from compensation is seen as normal. The amount of compensation perceived as due is assessed in reference to those already negotiated by other stakeholders with the wind farm operators. For example, recreational fishers belong in this category. They are poorly informed about the project because they are minimally involved in the consultation process. Their perceptions of the impacts on their activity are hazy, but they do not reject the idea of being compensated by the deployment of artificial reefs. This type of discourse is also adopted by a political figure who perceives no negative impact on the municipality but is trying to modify its boundaries to include the area to benefit from tax revenue.

- Non-sequitur discourse: "We have every kind of impact, we need jobs!"

Some impacts are perceived and compensation is expected, but there is no link between the two things. The presence of impacts is used as an argument to obtain compensation. For example, one mayor demands jobs because she believes that her municipality is the most heavily impacted. Here the challenge is to calculate the allocation of compensation across municipalities by reference to the impacts the offshore wind farm has on each of them. Non-sequitur discourse is also used by the hotel industry, which has sought to take advantage of the tax revenue in order to bring their facilities up to code.

- Reasonable discourse: "No net loss"

Here perceptions of impacts are accurate and planned compensation matches the expected impacts. Some of the compensation has already been negotiated with the project leader, commercial fishers are included in this group because of their early involvement in the consultation process. They now have an accurate understanding of the impacts of the wind farm on shellfish stocks. Compensatory measures can be directly calculated based on the impact on each fisher's catch. The accompanying measures should in part cover the loss of commercial activity during the construction phase and also repair of ecological damage (scallop reseeding, for example). These measures are rather loosely defined, as the outcome of bilateral negotiations, and may in the end result in overcompensation for the actual impacts. In this case, compensation is responsible for stakeholders' acceptance of the wind farm. While they were opposed to it initially, fishers now support it, conscious of the opportunities offered by compensation.

Institutional stakeholders' discourse of impact and compensation has enabled us to identify CoPs grouped around specific social representations associated with the planned offshore wind farm. The CoP approach seems to be an innovative way to address the maximum number of issues in combination. Some differences among the CoPs identified are not intuitive, for instance those between trawl fishers and scallop fishers. The size of the fishing gear used makes a difference and will produce different impacts for fishers. Also, the distinction between naturalist NGOs and associations for protection of the environment had not been recognised before these investigations. These organisations have the same status but support different interests. While naturalist NGOs defend the collective interest in conservation of biodiversity and habitats, environmental protection associations defend interests related to the environment at large and governance aspects of the project. While the interactions among stakeholders within each CoP are frequent, interactions between the two CoPs as a whole are almost non-existent. Finally, the distinction between types of recreational users is interesting. Those engaged in different activities will not be sensitive to the same elements of the environment, and may be concerned with different components of the bay's ecosystem: above the sea or under it, offshore or on land. 
The results of this study lead us to reassess our initial theoretical concepts and the adequacy of the figure representing the no-net-loss goal (Figure 1). We propose to improve this figure to better understand the mechanisms underlying the principle of no net loss (Figure 4). ES losses represented by area $A$ can be assessed in terms of each stakeholder's perceptions of impact and divided for each category of ES $\left(A_{1}, A_{2}, A_{3}\right)$. ES gains associated with compensation $B$ can be assessed on the basis of each subdivision in order to achieve the no-net-loss goal $\left(B_{1}, B_{2}, B_{3}\right)$. However, since the institutional stakeholders represent or defend a variety of interests, the risk that some of the ES will be "double-counted" is substantial. For example, impacts on fishing affect both commercial fishers and political figures (Table 2). An approach in terms of CoPs seems to be a more robust way to establish no net loss. Since each CoP has a direct relation to a specific category of ES (provisioning, regulating, or cultural), applying the principle of no net loss in terms of ES categories seems to be appropriate.

The continuation of this study will focus directly on CoPs in order to record their perceptions of the impacts on ES produced by the planned offshore wind farm in the bay of Saint-Brieuc and their claims for compensation. As we had anticipated, the CoP level seems the most appropriate for establishing a useful link with ecosystem services. This next step will require a larger number of interviews to obtain a representativeness of existing perceptions, because it includes a greater number of stakeholders. The results will be used to explore the no-netloss principle at the CoP level.

\section{Acknowledgements}

The authors would like to thank all the institutional stakeholders who took part in the survey for their time and contribution. The authors would also like to thank the Fondation de France for funding this research.

\section{References}

Amin A., J. Roberts (2008) Knowing in action: Beyond communities of practice. Research Policy (37) pp. 353-369.

Arias E., G. Fischer (2000) Boundary objects: Their role in articulating the task at hand and making information relevant to it. International ICSP Symposium on Interactive and Collaborative Computing, December 2000.

Arnold A. (2004) A review of public attitudes towards marine issues within and beyond New Zealand. Science International Series (170).

Augris C., D. Hamon (1996). Atlas thématique de l'environnement marin en baie de SaintBrieuc (Côtes-d'Armor). Ifremer.

Bertin S. (2011) État des lieux du patrimoine culturel maritime du golfe normand-breton. Agence des Aires Marines Protégées.

Boehlert G., A. Gill (2010) Environmental and ecological effects of ocean renewable energy development: A current synthesis. Oceanography 23(2) pp. 68-81.

Busch M., K. Gee, B. Burkhard, M. Lange, N. Stelljes (2011) Conceptualizing the link between marine ecosystem services and human well-being: the case of offshore wind farming. International Journal of Biodiversity Science, Ecosystem Services and Management. 
CAS (Centre d'Analyse Stratégique) (2009) Approche économique de la biodiversité et des services liés aux écosystèmes, rapport de la mission présidée par Bernard Chavassus-auLouis, coll. Rapports et documents, No. 18, la documentation française.

Château P-A., Y-C. Chang, H. Chen (2012) Building a stakeholder's vision of an offshore wind-farm project: A group modeling approach. Science of the Total Environment (in press).

Cole S. (2009) "How much is enough?" Determining adequate levels of environmental compensation for wind power impacts using equivalency analysis: An illustrative and hypothetical case study of sea eagle impacts at the Smøla Wind Farm, Norway. Epsilon Open Archive Publishing, Swedish Agricultural University.

Cuperus R., K. Canters, H. Udo de Haes, D. Friedman (1999) Guidelines for Ecological Compensation Associated with Highways. Biological Conservation 90(1) pp.41-51.

Devine Wright P., Y. Howes (2010). Disruption to place attachment and the protection of restorative environments: $A$ wind energy case study. Journal of Environmental Psychology (30) pp. 271-280.

Dunford R., T. Ginn, W. Desvousges (2004) The use of habitat equivalency analysis in natural resource damage assessment. Ecological Economics (48) pp. 49-70.

European Commission (2008) Climate change: Commission welcomes final adoption of Europe's climate and energy package. RAPID Press Release, Brussels, IP/08/1998.

Firestone J., W. Kempton (2007) Public opinion about large offshore wind power: Underlying factors. Energy Policy (35) pp. 1584-1598.

Freeman R. (1984) Strategic management: A stakeholder approach. Boston: Pitman.

Gastineau P., E. Taugourdeau (2014) Compensating for environmental damages. Ecological Economics (97) pp.150-161

Gee K., B. Burkhard (2010) Cultural ecosystem services in the context of offshore wind farming: A case study from the west coast of Schleswig-Holstein. Ecological Complexity (7) pp. 349-358.

Gill B. (2005) Offshore renewable energy: ecological implications of generating electricity in the coastal zone. Journal of Applied Ecology (42) pp. 605-615.

Gobert J. (2010) Ethique environnementale, remédiation écologique et compensations territoriales. VertigO - La revue en sciences de l'environnement (10).

Gray T., C. Haggett, D. Bell (2005) Offshore wind farms and commercial fisheries in the UK: A study in stakeholder consultation. Ethics, Place and Environment 8 (2) pp. 127-140.

Habermas J. (1984) Reason and the Rationalization of Society, Volume 1 of The Theory of Communicative Action. English translation by Thomas McCarthy. Boston: Beacon Press

Haggett C. (2011) Understanding public responses to renewable energy. Energy Policy (39) pp. 503-510.

Hein L., K. van Koppen, R. de Groot, E. van lerland (2006) Spatial scales, stakeholders and the valuation of ecosystem services. Ecological Economics (57) pp. 209-228.

Inger R., M. Attrill, S. Bearhop, A. Broderick, W.J. Grecian, D. Hodgson, C. Mills, E. Sheehan, S. Votier, M. Witt, B. Godley (2009) Marine renewable energy: Potential benefits to biodiversity? An urgent call for research. Journal of Applied Ecology (46) pp. 1145-1153.

Johnson G., K. Scholes (1999) Exploring corporate strategy (5 $5^{\text {th }}$ edition). Prentice Hall, Harlow, UK.

Kuehn S. (2005) Social investigation of the reception of Horns Rev and Nysted offshore wind farms in the local communities. Annual status report 2003 to Elsam Engineering. 
Ladenburg J., A. Dubgaard (2009) Preferences of coastal zone user groups regarding the siting of offshore wind farms. Ocean and Coastal Management (52) pp. 232-242.

Ladenburg J., B. Möller (2011) Attitude and acceptance of offshore wind farms-the influence of travel time and wind farm attributes. Renewable and Sustainable Energy Reviews 15(9) pp. 4223-4235.

Levrel H. (2006) Biodiversité et développement durable: quels indicateurs? Doctoral thesis directed by J. Weber, Ecole des Hautes Etudes en Sciences Sociales.

Levrel H., Doyen L., Julliard R., Kerbiriou C., Couvet, D. (2007) Etude de faisabilité pour la réalisation d'un Millennium Ecosystem Assessment en France. Direction de la nature et des paysages, Ministère de l'écologie et du développement durable.

Mangi S. (2013) The impact of offshore wind farms on marine Ecosystems: A review taking an ecosystem services perspective. Proceedings of the Institute of Electrical and Electronics Engineers 101(4). p.999-1009

McKenney B., J. Kiesecker (2010) Policy development for biodiversity offsets: A review of offset frameworks. Environmental Management (45) pp. 165-176.

MEA (Millennium Ecosystem Assessment) (2005) Ecosystems and Human Well-being: Synthesis. Island Press, Washington DC.

Mitchell R., B. Agle, D. Wood (1997) Toward a theory of stakeholder identification and salience: Defining the principle of who and what really counts. The Academy of Management Review 22(4) pp. 853-886.

Pearce D., R. Turner (1990) Economics of natural resources and the environment. BPCC Wheatsons Ltd., Exeter, UK.

Pomeroy R., F. Douvere (2008) The engagement of stakeholders in the marine spatial planning process. Marine Policy (32) pp. 816-822.

Quétier F., S. Lavorel (2011) Assessing ecological equivalence in biodiversity offset schemes: Key issues and solutions. Biological Conservation 144(12) pp. 2991-2999

Röling N., M. Wagemakers (1998) Facilitating sustainable agriculture: Participatory learning and adaptive management in times of environmental uncertainty, Cambridge: Cambridge University Press.

Still D. (2001) Offshore wind at Blyth. Renewable Energy (24) pp. 545-551.

UICN (2011) La compensation écologique: état des lieux et recommandations. Paris, France.

Wenger E. (1998) Communities of practice: Learning, meaning, and identity. Cambridge University Press, Cambridge.

Wenger E. (2000) Communities of practice and social learning systems. Organization 7(2) pp. 225-246. 


\begin{tabular}{|c|c|c|c|c|}
\hline & Institutional stakeholders interviewed & Location & $\begin{array}{c}\text { Geographical scope of } \\
\text { activity }\end{array}$ & $\begin{array}{c}\text { Interests } \\
\text { represented or defended }\end{array}$ \\
\hline \multirow{3}{*}{ Political figures } & Mayor & Erquy & Municipality & Inhabitants \\
\hline & Mayor & Saint-Quay Portrieux & Municipality & Inhabitants \\
\hline & Energy project manager of the General Council & Saint-Brieuc & County & Electricity consumption goals \\
\hline \multirow{3}{*}{$\begin{array}{c}\text { Managers } \\
\text { of natural areas }\end{array}$} & Nature reserve conservator & Hillion & Nature reserve & Biodiversity / Natura 2000 species \\
\hline & Nature reserve employee & Hillion & Nature reserve & Biodiversity / Natura 2000 species \\
\hline & Director of mixed syndicate in charge of regional activities & Plévenon & Inter-municipalities & Natura 2000 species \\
\hline \multirow{4}{*}{ Economic actors } & Director of an economic development association & Saint-Brieuc & County & Industrial companies and fishers \\
\hline & Employee of an economic development association & Saint-Brieuc & County & Industrial companies and fishers \\
\hline & $\begin{array}{l}\text { Chamber of Commerce and Industry (CCI) business } \\
\text { consultant }\end{array}$ & Ploufragan & County & Industrial companies \\
\hline & CCI director of development companies & Ploufragan & County & Industrial companies \\
\hline \multirow{2}{*}{$\begin{array}{c}\text { Heads of public } \\
\text { organisations }\end{array}$} & Head of an environmental organisation & Saint-Brieuc & Local & Biodiversity /Organisation members \\
\hline & President of an anti-wind collective & Erquy & Local & Members of the collective \\
\hline \multirow{5}{*}{$\begin{array}{l}\text { Recreational } \\
\text { associations }\end{array}$} & Director of a sailing club & Erquy & Municipality & Sailors \\
\hline & Director of a scuba diving club & Erquy & Municipality & Scuba divers \\
\hline & President of a regatta committee & Pléneuf Val-André & Municipality & Association members \\
\hline & President of a recreational fishing committee & Saint-Quay Portrieux & County & Recreational fishers \\
\hline & Vice-president of a recreational fishing committee & Saint-Quay Portrieux & County & Recreational fishers \\
\hline \multirow{4}{*}{$\begin{array}{l}\text { Commercial } \\
\text { fishers }\end{array}$} & Person in charge of environment, fishery committee & Paimpol & County & Fishers \\
\hline & Person in charge of environment, fishery committee & Rennes & Region & Fishers \\
\hline & Person in charge of environment, fishery committee & Saint-Malo & County & Fishers \\
\hline & Vice-president of a fishery committee & Paimpol & County & Fishers \\
\hline \multirow{3}{*}{$\begin{array}{l}\text { Industrial wind } \\
\text { companies }\end{array}$} & Project manager of the offshore wind-farm project & Saint-Brieuc & Local & Wind farm operator \\
\hline & Person in charge of environment, offshore wind developer & Lorient & Local & Wind farm developer \\
\hline & Person in charge of consultation, offshore wind developer & Lorient & Local & Wind farm developer \\
\hline
\end{tabular}

Table 1. List of interviewed stakeholders and their main characteristics 


\begin{tabular}{|c|c|c|c|c|}
\hline & $\begin{array}{l}\text { Provisioning } \\
\quad \text { ES }\end{array}$ & $\begin{array}{c}\text { Regulating } \\
E S\end{array}$ & $\begin{array}{l}\text { Cultural } \\
\text { ES }\end{array}$ & Expected compensation \\
\hline Political figures & $\begin{array}{l}+/- \\
\text { Provision of food/ } \\
\text { provision of } \\
\text { electricity }\end{array}$ & $\begin{array}{l}+/ \text { - } \\
\text { Global climate } \\
\text { regulation / Local } \\
\text { regulating ES }\end{array}$ & Landscape & $\begin{array}{l}\text { Tax revenue } \\
\text { Job creation in farm maintenance } \\
\text { Compensation of fishers }\end{array}$ \\
\hline $\begin{array}{l}\text { Managers of natural } \\
\text { areas }\end{array}$ & $\begin{array}{l}\stackrel{+}{\text { Provision of food }} \\
\text { (reserve effect })\end{array}$ & $\begin{array}{l}+/ \text { - } \\
\text { Global climate } \\
\text { regulation / Local } \\
\text { regulating ES }\end{array}$ & 0 & \\
\hline $\begin{array}{l}\text { Economic } \\
\text { actors }\end{array}$ & $\begin{array}{l}+ \\
\text { Provision of } \\
\text { electricity }\end{array}$ & 0 & $\begin{array}{c}+ \\
\text { New cultural } \\
\text { activities }\end{array}$ & \\
\hline $\begin{array}{l}\text { Heads of public } \\
\text { organisations }\end{array}$ & 0 & Local regulating ES & Landscape & $\begin{array}{l}\text { No expected compensation for two reasons: } \\
\text { Expectation of Environmental Impact Assessment and } \\
\text { opposition to the planned offshore wind farm }\end{array}$ \\
\hline $\begin{array}{l}\text { Recreational } \\
\text { associations }\end{array}$ & 0 & 0 & $\begin{array}{l}\text { - } \\
\text { Seascape and } \\
\text { biodiversity }\end{array}$ & $\begin{array}{l}\text { Project development associated with } \\
\text { the offshore wind farm } \\
\text { Deployment of artificial reefs } \\
\text { Collective financing of materials }\end{array}$ \\
\hline Commercial fishers & Provision of food & Local regulating ES & 0 & $\begin{array}{l}\text { Individual indemnities } \\
\text { Collective financing of projects } \\
\text { Job financing } \\
\text { Slipper limpet eradication } \\
\text { Scallop reseeding }\end{array}$ \\
\hline $\begin{array}{l}\text { Industrial wind } \\
\text { companies }\end{array}$ & $\begin{array}{l}+ \\
\text { Provision of } \\
\text { electricity }\end{array}$ & $\begin{array}{l}\stackrel{+}{\text { Global climate }} \\
\text { regulation and } \\
\text { artificial reef }\end{array}$ & $\begin{array}{c}+ \\
\text { New cultural } \\
\text { activities }\end{array}$ & \\
\hline
\end{tabular}

Table 2. Qualitative analysis of institutional discourses about perceived impacts

("+": positive impact or benefit; "-": negative impact; "+/-": both negative and positive impacts; "0": no perceived impact) 


\begin{tabular}{|c|c|c|c|}
\hline Identified CoP & $\begin{array}{l}\text { Expectation of } \\
\text { perceived impacts }\end{array}$ & $\begin{array}{l}\text { Ecosystem } \\
\text { services } \\
\text { impacted }\end{array}$ & $\begin{array}{c}\text { Main characteristics } \\
\text { of the CoP }\end{array}$ \\
\hline Scallop fishers & Scallops & \multirow{2}{*}{$\begin{array}{l}\text { Provisioning } \\
\text { ES }\end{array}$} & \multirow{2}{*}{ Constrained by the fishing gear used } \\
\hline Trawl fishers & Fishing area & & \\
\hline Naturalist NGOs & $\begin{array}{l}\text { Ecological habitats } \\
\text { Natura } 2000 \text { species }\end{array}$ & \multirow{2}{*}{$\begin{array}{l}\text { Regulating } \\
\text { ES }\end{array}$} & $\begin{array}{c}\text { Supports protection of the ecosystem as an } \\
\text { ecological entity }\end{array}$ \\
\hline $\begin{array}{l}\text { Associations for } \\
\text { environmental } \\
\text { protection }\end{array}$ & $\begin{array}{l}\text { Ecological habitats } \\
\text { Landscape }\end{array}$ & & $\begin{array}{c}\text { Supports protection of the landscape; } \\
\text { Focused on governance aspects of the } \\
\text { project }\end{array}$ \\
\hline Tourists & Seascape & \multirow{2}{*}{$\begin{array}{l}\text { Cultural } \\
\qquad E S\end{array}$} & $\begin{array}{c}\text { Focused on enjoyment of the natural } \\
\text { landscape }\end{array}$ \\
\hline $\begin{array}{l}\text { Recreational users: } \\
\text { Sailors } \\
\text { Scuba divers } \\
\text { Recreational fishers }\end{array}$ & $\begin{array}{c}\text { Seascape } \\
\text { Submarine seascape } \\
\text { Target species }\end{array}$ & & $\begin{array}{c}\text { Supports the provision and high standards } \\
\text { of recreational activities }\end{array}$ \\
\hline
\end{tabular}

Table 3. Communities of practice and their perceptions of impact and compensation 


\section{Figures}

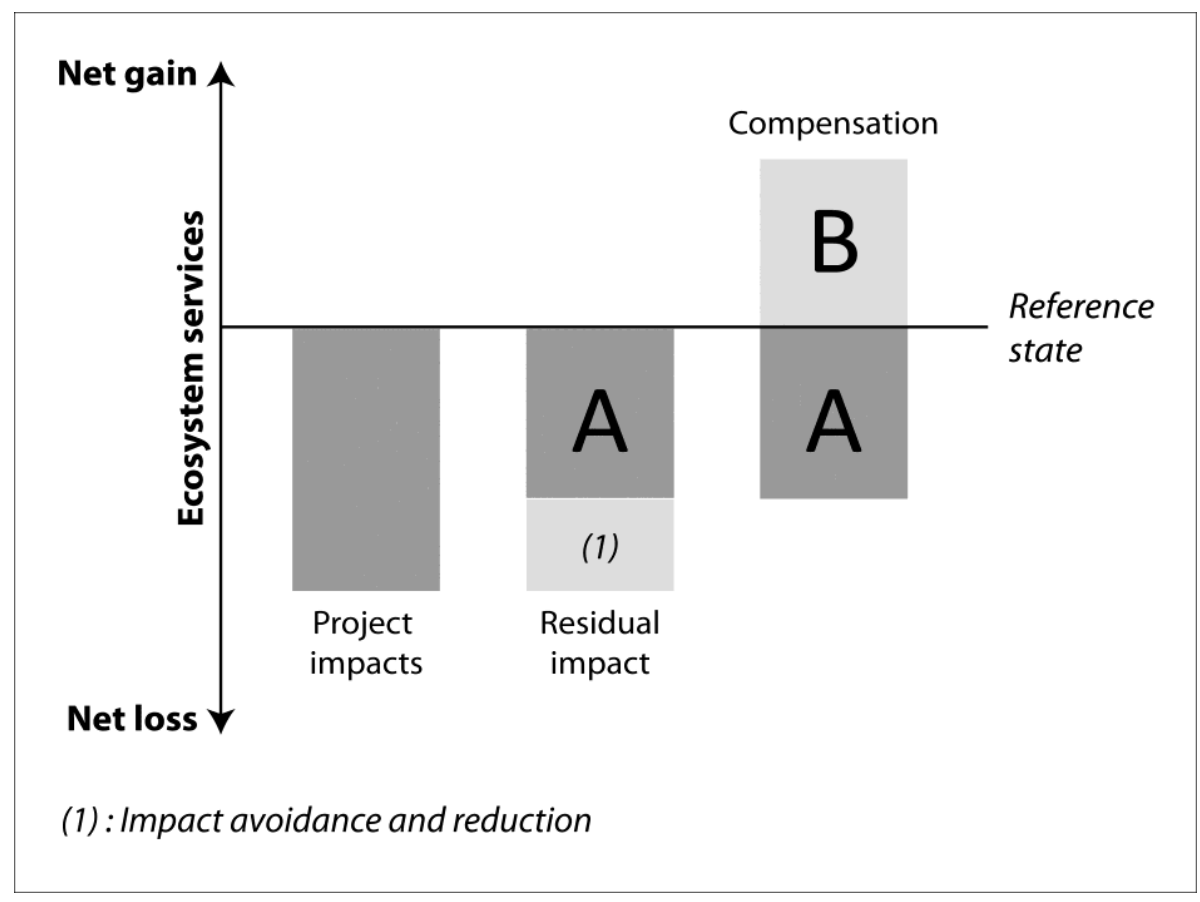

Figure 1. Residual impact to be compensated for in order to achieve the no-net-loss goal (adapted from Quétier and Lavorel, 2011). In this diagram, ES loss created by wind farm deployment which couldn't be avoided or reduced is represented by area A. Compensations are implemented (area B) in order to maintain the initial level of ES (reference state). To achieve the no-net-loss goal, area A has to be equivalent to area B. 


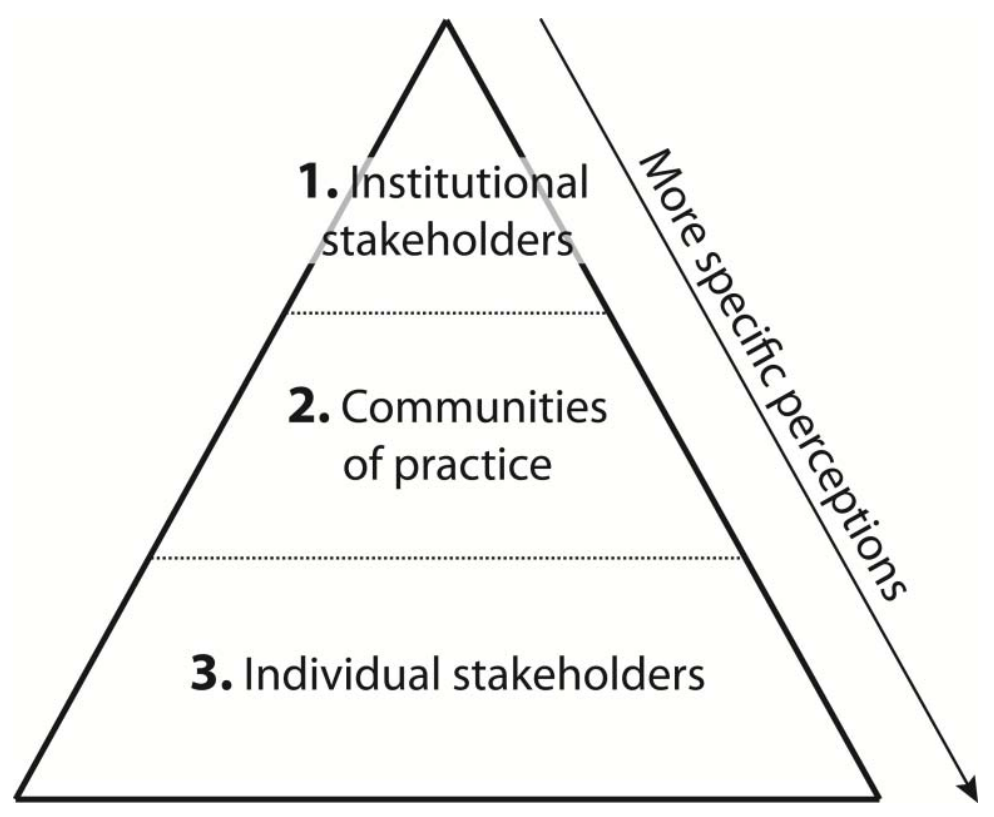

Figure 2. Vertical division of stakeholders in our study

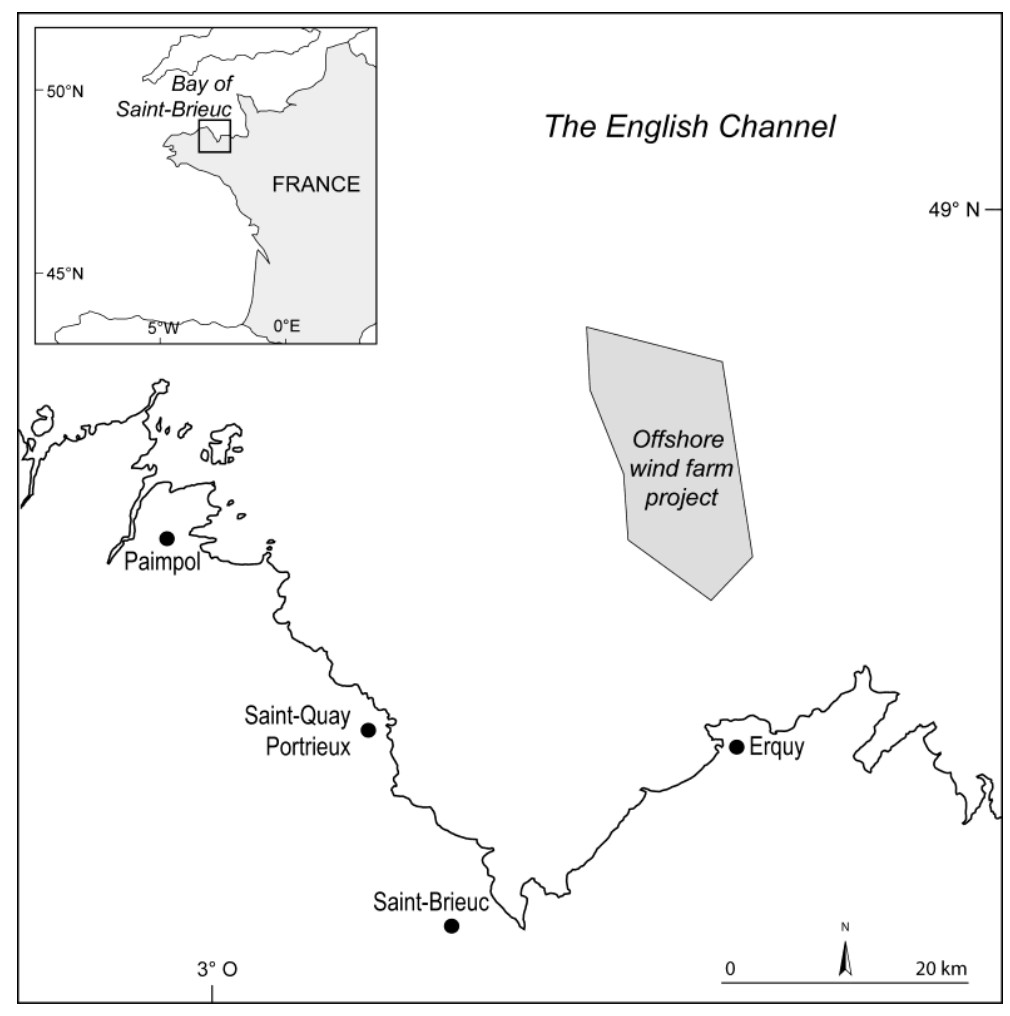

Figure 3. Location of the case study site 


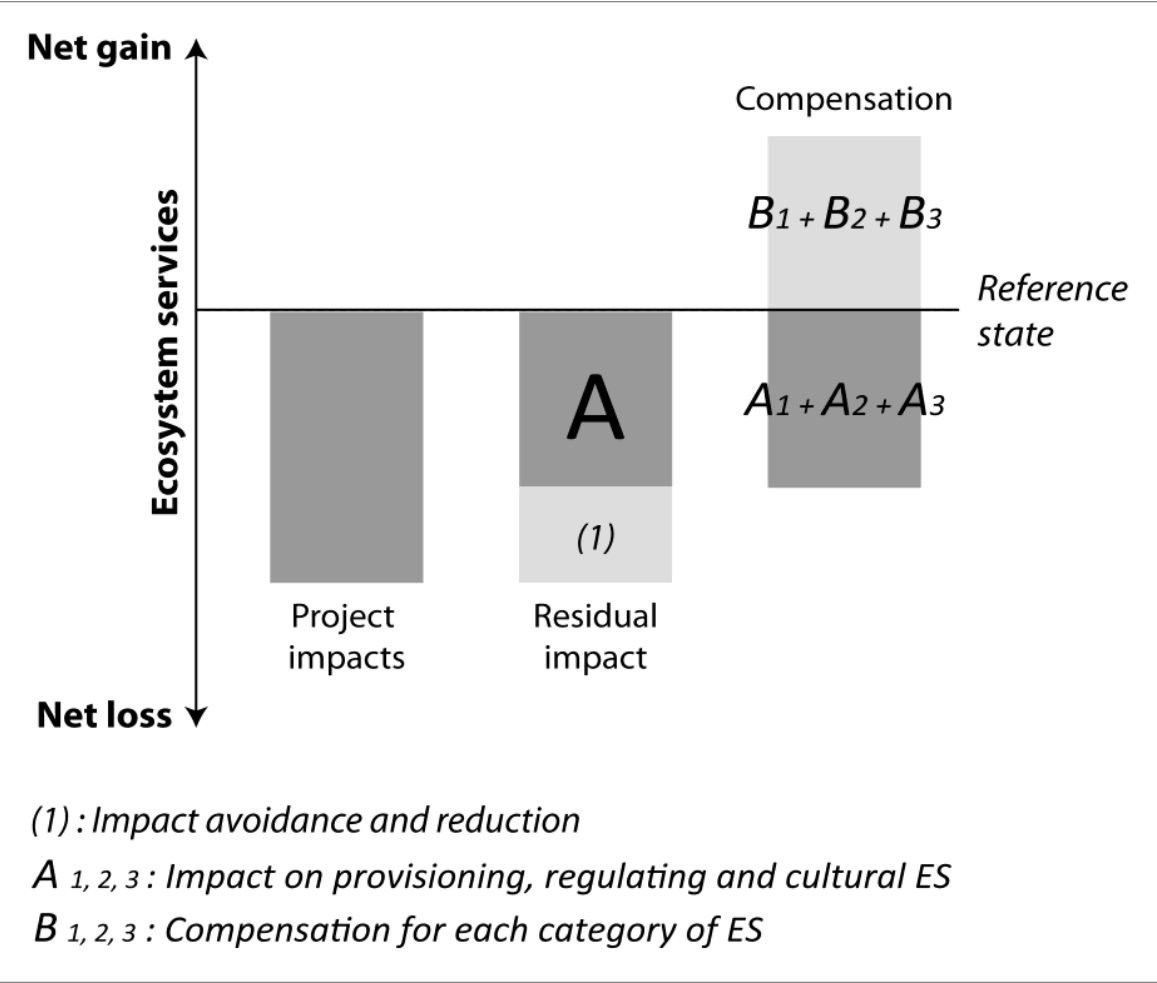

Figure 4. Residual impact to be compensated for in order to achieve the no-net-loss goal, Figure 1 enhanced (adapted from Quétier and Lavorel, 2011). To achieve the no-net-loss goal, area $A_{n}$ has to be equivalent to area $B_{n}$. 